\title{
Design of Information System in Admission of New Students Based on Web in SMK Al Amanah
}

\author{
Andri Cahyo Purnomo ${ }^{1}$, Bayu Pramono ${ }^{2}$, Fitra Putri Oganda ${ }^{3}$ \\ 1,2,3 Raharja University, JL. Jendral Sudirman No.40 Modern Cikokol Tangerang \\ e-mail: andricahyo@raharja.info,bayupramono@raharja.info,fitra.putri@raharja.info
}

\begin{abstract}
This research has the aim of building a system of acceptance for new students with a website-based method, so that it can help prospective new students in the subject make it easier to obtain information about the registration of new students. Data processing in the acceptance of new students at Al Amanah Vocational School Pasar Kemis still uses Conventional systems, namely prospective registrants come directly to the school then fill out the registration form then the registration data is recorded in a book and reports are made also using manual recapitulation resulting in archival loss and needing a very long time in the process of making a report. Using research methods namely Library Studies, Analysis, Observation, Designing, Trial and Implementation. The information system at the admission of new students is designed using the PHP programming language and using the MySQL database as a Database Server. The output of this research is that the information system on admission of new students with web-based can have the ability to provide convenience for parents of new students in terms of getting all information about acceptance to new students and doing the registration process flow online.
\end{abstract}

Keywords: New Student Admissions, PHP, MySQL Database.

\section{Introduction}

In general, information technology has an important role in the role of humans, this matter can automate tasks or processes, strengthen in the role of humans, that is, can provide information on a project, process and support in relation to connecting projects and processes such as at student acceptance new. Based on this understanding, the information technology presented at this time has provided a potential and is also a great potential that is used and used as well as possible. The quality of education in Indonesia is still very alarming to date. This condition can be seen from the average ability of students in Indonesia which is still very low, so that the achievement they have obtained is not optimal. The low level of education is inseparable from the problems that arise during the learning process takes place. [1]

To design a student registration information system, it is necessary to take several sources that are used in making information systems including primary data obtained from research respondents. The primary data is obtained from the literature as a framework in system design and database creation, surveys where data is obtained from interviews in the form of information that will later be used as a reference for what should be displayed in web-based information systems and direct observation to study the registration system that is running on a university $X$. For secondary data obtained in the design in the form of data obtained from several students who are in a college $\mathrm{X} .[2]$

Al Amanah Vocational School is one of the schools that is engaged in vocational education, but has things that may not be good in the input system process at the acceptance of new students, because in the input process it still uses a conventional or manual system with a bookkeeping form so that an error occurs when inputting student data on the PSB committee. This can be a motivation for 
researchers to be able to enlighten the world of education in order to achieve success. Information systems at the reception of new students must implement a computerized system that is representing one of the assistance for fluency in the field of education so that the new student admission process can be more precise and accurate.

The picture above is a menu settings display for the initial setup of the company,to help with the data management process which contains information about the company [3]. Information displayed such as Logo, Company Name, Company Address, Company Delivery Address, Phone, Fax, NPWP, Website, Email [4]. This company's email may differ from the user's email used to log in to the Journal application as it will be used to send invoices and delivery slips. All in the form of information about the company [5].

In this matter, the researcher agreed to give an agreement with the system on student admission by the web, considering that the Al Amanah Vocational School still uses conventional systems, using system inputs that are still not good at receiving new students, because the input process is still running with manual input made in bookkeeping so that it often creates problems when inputting and the difficulty of inputting student data by the admin. By making it a website to accept new students in this school, it is expected that the Al Amanah Vocational School can make a good name in the surrounding community or other areas so that it is easy to register with new prospective students. Another thing is that currently there are a lot of school registration systems that do online media. At this time Al Amanah Vocational School is still implementing a system where it does not yet have a site that provides information and promotional media on the acceptance of new students with the website at the school, the things that have been described here. : "DESIGNING INFORMATION SYSTEMS IN ADMISSION OF NEW STUDENTS WITH WEB BASED IN AL AMANAH VOCATIONAL SCHOOL"

\section{Research Method}

Based on the results of the analysis, observations and interviews of researchers with administrative staff who think that the activities of admitting new students to Al Amanah Vocational School Pasar Kemis are still applying conventional systems or have not used a computerized system, so that the new students need to take the time quite long and requires more thought. The researcher wants to try to be able to analyze and describe some of the obstacles and problems that exist in this running system. The main obstacles and problems are the work methods that are still simple and still manually, which can be described as follows:

a. During this time it can take quite a long time because the system still uses a manual system.

b. The high number of errors in the calculation of the study and the recording of the names of students in the new student admission report caused by humans.

c. There is a delay in information and storage of evidence of student acceptance that is not well organized.

d. Requires a long time if you want to find student data. The process of making a new student admission report is not fast, precise and accurate.

\section{Literature Review}

In this literature study it can be easier for researchers to find references and relevant information by finding more information towards research that is in accordance with the topic of the problem that is the object of research, by reading books or existing literature so that opinions from various experts on a problem. There are several Library Studies that have been carried out in previous studies on the New Student Admissions Information System and other related research. Here are 5 (five) literature reviews including: 
1. Research conducted by Nurul Azizah Yaoma Ramadhani, on Journal Speed - Sentra Penelitian Engineering dan Edukasi - Vol 3 No 3 (2011) by title "Pembangunan Sistem Informasi Penerimaan Siswa Baru Di Sekolah Menengah Kejuruan Al-Irsyad Tegal", in this study said that its application to the Al-irsyad Tegal Vocational School had been done manually or had been computerized but was computerized in other cases using Microsoft Office Excel, which it felt still had a lot of data deficiencies, then used test value calculations manually which might an error can occur. For that we need an information system that can help the acceptance process for new students. This study uses research methods such as literature studies, observation, interviews, analysis, design, trial and implementation. The conclusion of this study is that it is expected that an information system can be formed at the acceptance of new students with web-based.[6]

2. Research conducted by Lely Deviana Putrid and Azis Ahmadi, from Universitas Yudharta Pasuruan on IJNS - Indonesian Journal on Networking and Security Vol 3, No 4 (2014) with title "Perancangan Sistem Informasi Penerimaan Siswa Baru Pada Sekolah Menengah Kejuruan Negeri 3 Pacitan" in this study discusses the existence of an information system that has been based on computerization and database applications that are expected to help deliver information easily and precisely and facilitate the implementation of data processing and management in acceptance of new students. This research uses the method of interview research, observation, literature study, analysis, system design, testing, and implementation. The hope of this study is that the information system created can provide convenience in the implementation of new student admission activities at the State Vocational School 3 Pacitan.[7]

3. Research conducted by Sidiq Wahyu Surya Wijaya, Agus Mulyanto dan M. Mustakim from UIN Sunan Kalijaga Yogyakarta on SEMINAR NASIONAL VI SDM TEKNOLOGI NUKLIR with title "Sistem Informasi Penerimaan Mahasiswa Baru Berbasis WEB dan WAP" in this study states that the information system on the acceptance of new students with web-based already has the ability that can provide convenience for prospective new students to obtain all information regarding admissions to new students who do the registration process flow and payment confirmation of registration online. For prospective students who do not have computers connected to the internet, they can still feel the ease of being able to access this system by using mobile phones equipped with WAP facilities.[8]

4. Research conducted by Muhamad Muslihudin and Anggun Larasati from STMIK Pringsewu on Jurnal TAM (Technology Acceptance Model) Vol 3 (2014) with title "Perancangan Sistem Aplikasi Penerimaan Mahasiswa Baru Di STMIK Pringsewu Menggunakan PHP dan MySQL", in this study discusses that by using this application system, better service quality is expected. For example, in registering prospective new students who can register online without having to come directly to the secretariat room. By using this application system it is expected to facilitate archiving accurate files and avoid redundancy. An example is online registration. New student data can be directly seen at the time of inputting, so data redundancy does not occur in registration.[9]

5. Research conducted by Naely Farkhatin from Universitas Indraprasta PGRI on Faktor Exacta Vol. 5 No. 2: 124-132 with title "Perancangan Sistem Informasi Penerimaan Siswa Baru" in this study discusses about Ciputat Tangerang Banten Nusantara Vocational School is one of the institutions in the field of education where in the processing of new student admissions data is still not implementing a special application conventional alias, so that it causes the work results achieved are not optimal and take enough time long. Therefore a design of an information system of acceptance is made in new students using Borland Delphi programming, where the program is expected to be able to overcome the problems that occur in the process of admitting new students at Ciputat Nusantara Vocational School, Tangerang, Banten.[10]

This web-based new student admission system was created as a development of the old 
system. In the sense that the process that is in the new system is a combination of processes on the old system coupled with processes on the new system that are carried out online. Merging these two processes is expected to solve the problems that often occur.

\section{Results and Analysis}

In overcoming the problems that have been mentioned, the researcher proposes a way to minimize the problems in the process of accepting new students so that they are better than before, namely implementing a computerized system with the following considerations:

1. Time efficiency in the process of calculation and reporting becomes faster.

2. High accuracy, the possibility to occur in the calculation and recording is relatively smaller.

3. High data volume because it is able to process large amounts of data.

Data is safe, because data is stored in a computer which is a communication medium that can quickly present the information needed.

\subsection{Design Prototype}

This stage is a description of the system or prototype using mockup. The following is a prototype or display of system design Acceptance of students to be made.

A. Draft Login Menu

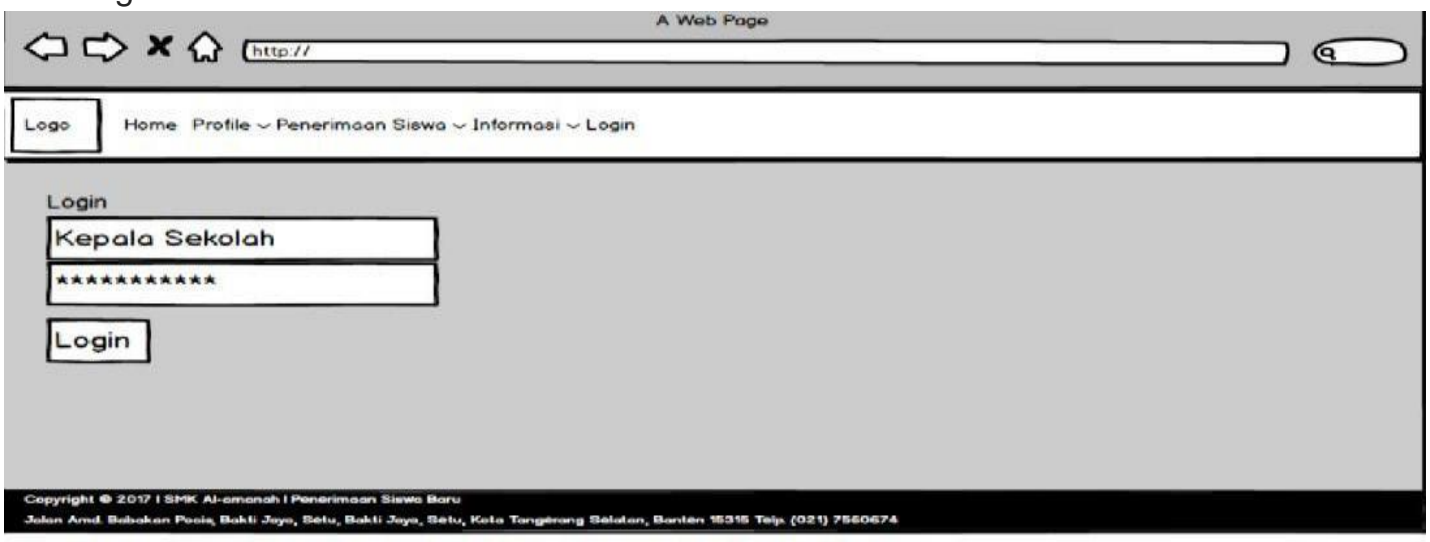

Figure 1. Draft Login Menu.

Figure 1. explain the process of students and headmaster to access the site and log in to their account

B. Draft Registration Form 


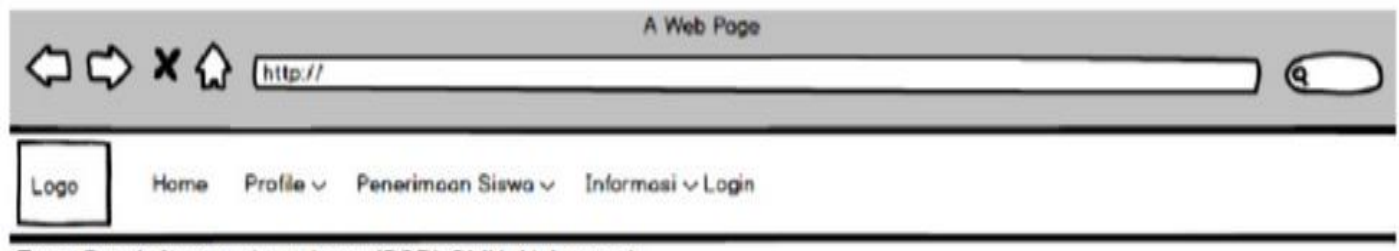

Form Pendaftaran siswa baru (PSB) SMK AI Amanah

L. Identitas peoerte didk

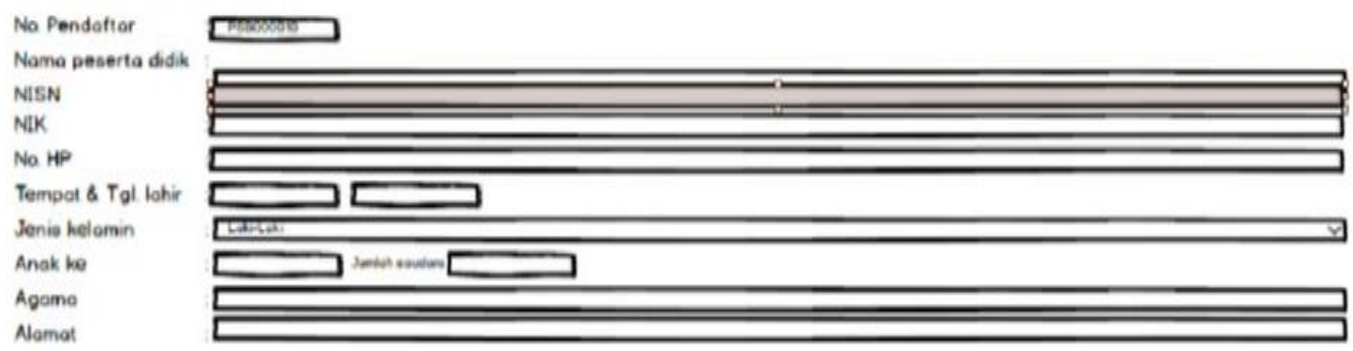

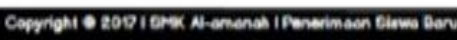

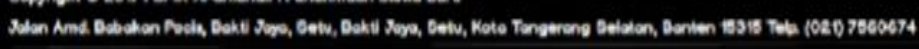

Figure 2. Draft Registration Form

Figure 2. explain the flow of the account registration process if you don't have

access C. Draft Test Schedule

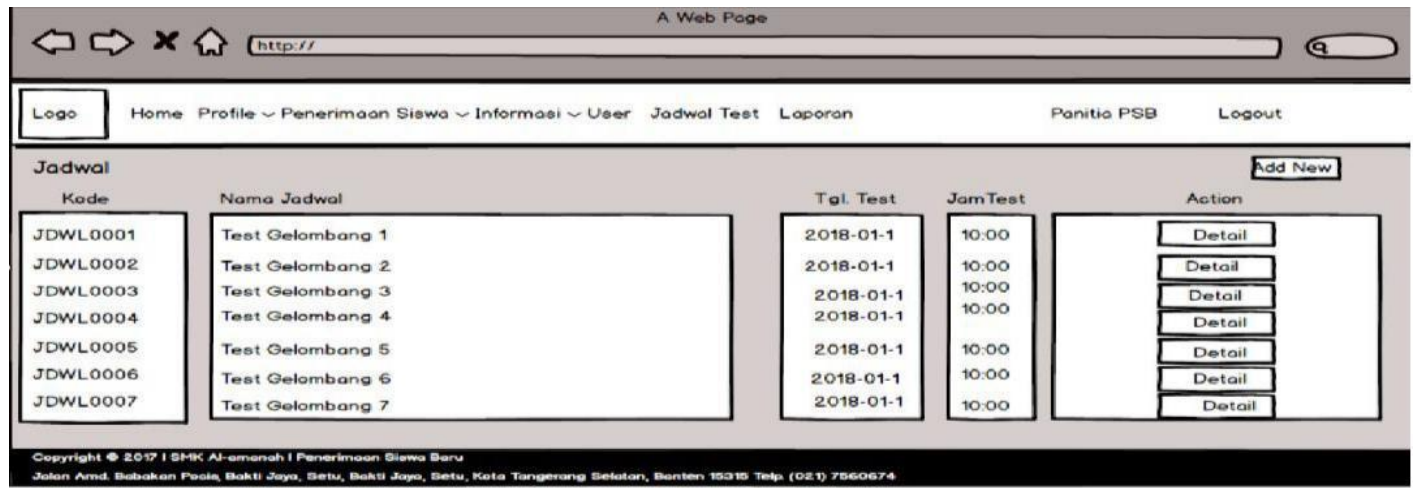

Figure 3. Draft Test Schedule

Figure 3. Explain scheduling information to take the entrance test by taking the selection test

D. Draft Home Design on the Website

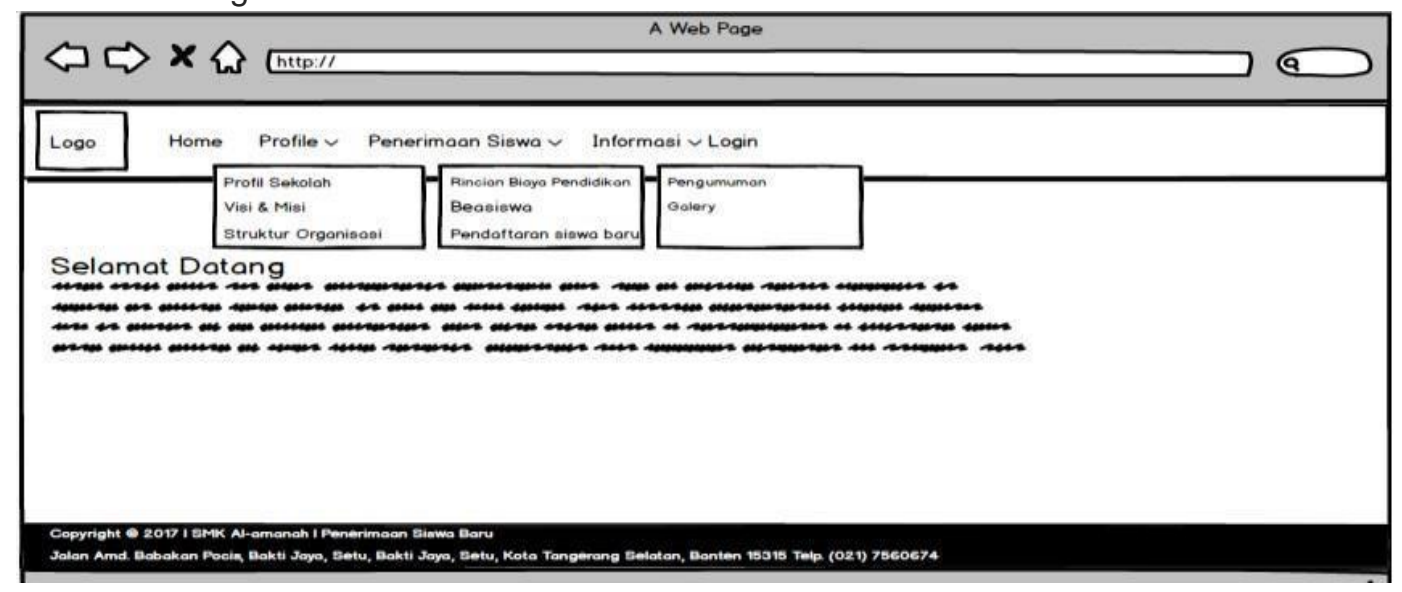

Figure 4. Home Design on the Website 
Figure 4. is a design design for the display of the home on the website with various features provided.

E. Draft Prospective Student Report

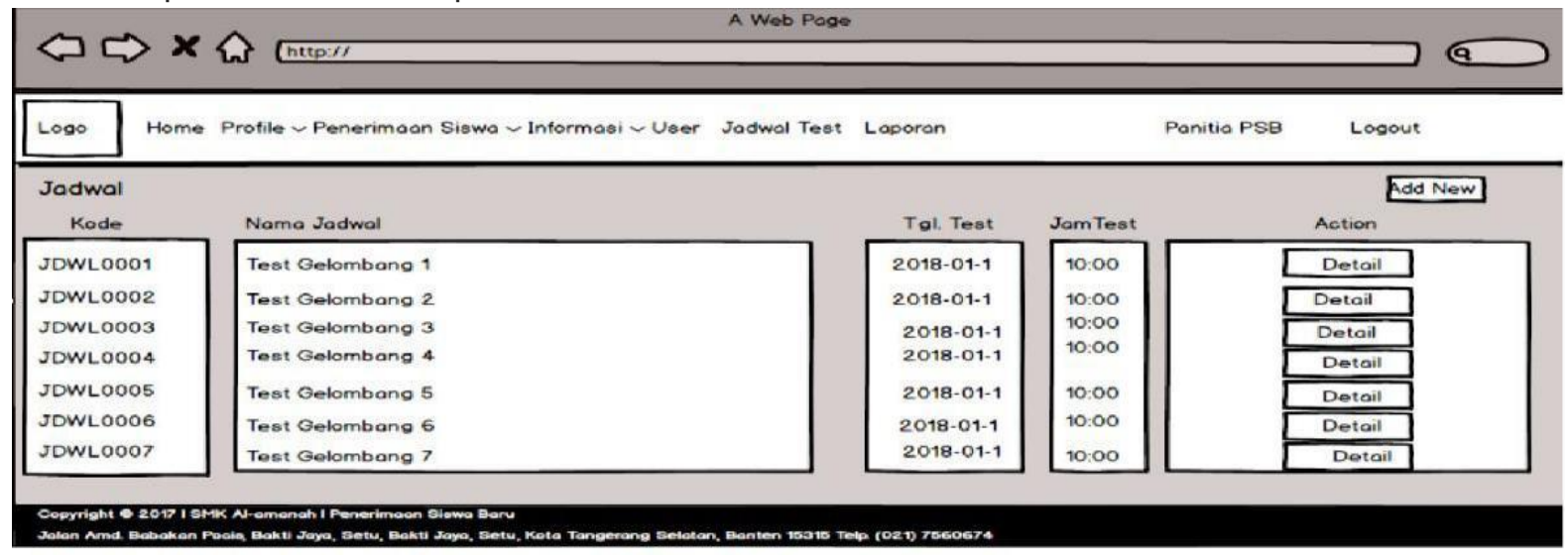

Figure 5. Draft Prospective Student Report

\subsection{Program Design}

- Display Login

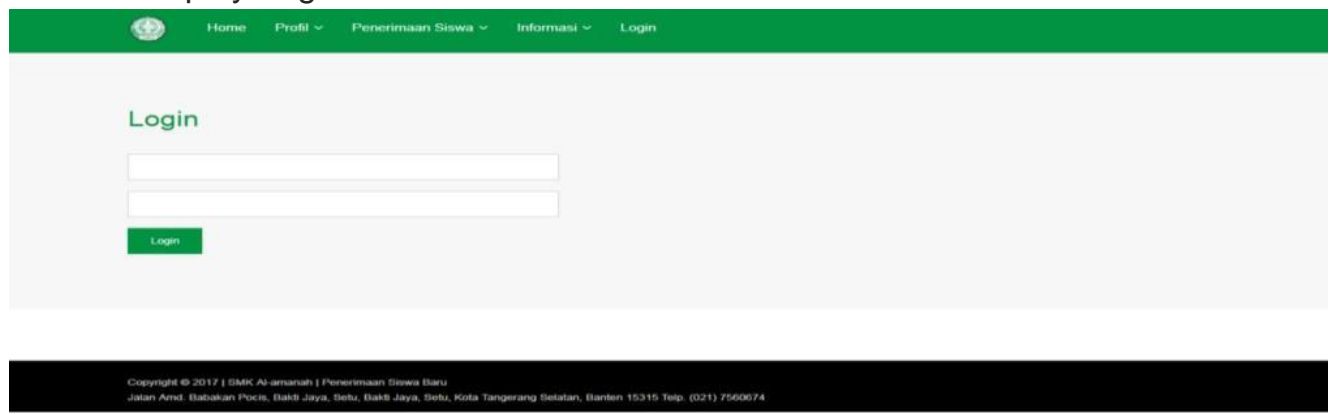

Figure 6. Display Login

Figure 6. is the result of a design draft made with a prototype, when visiting the site it will be directed to the login page as shown above.

- Home View on the Website

Selamat Datang

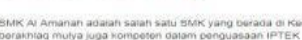

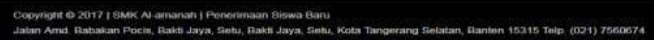

\section{Figure 7. Home View on the Website}

Figure 7. is the result of the design of the home view design, where when accessing the site and clicking on the home menu a text will appear welcome and news about the Al Amanah Vocational School.

- Display Registration Form 


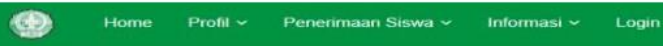

Form Pendaftaran Siswa Baru (PSB) SMK Al-amanah

1. Identitas Peserta Didik

No. Pencataran

Nama Peserta Didik:

Nisn

NIK

No. HP

Temoat \& Tol. Lahit

Jenis Kotamin

Anak ke

Agama

Alamat

11. Identitas Sekolah Asal

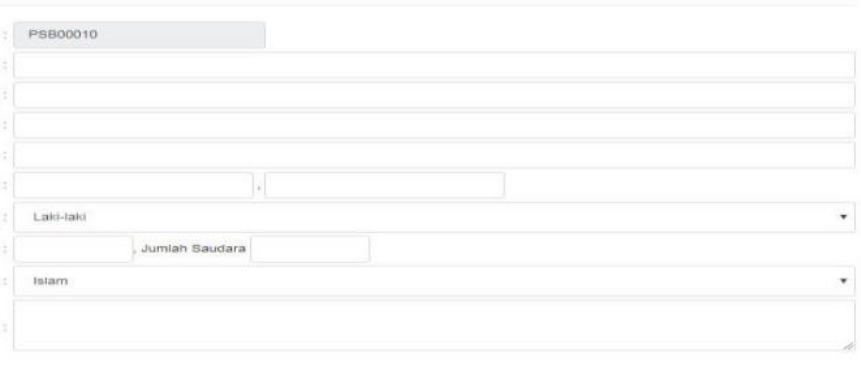

Figure 8. Display Registration Form

Figure 8. It is the result of the implementation of the design prototype design for the registration form, in which prospective students must fill in their data and needs for school.

- Display of school Profiles

\section{(1) Home Profll - Penerimaan Siswa - Informasi - Login}

Profil SMK Al-amanah

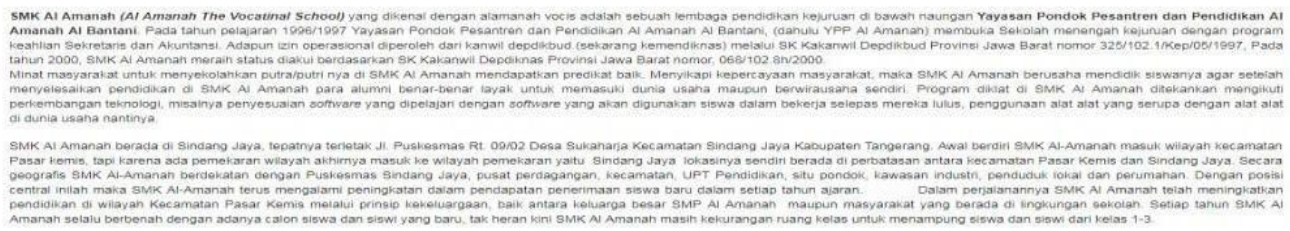

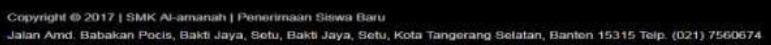

Figure 9. Display of School Profiles

- $\quad$ Display of Prospective Student Reports

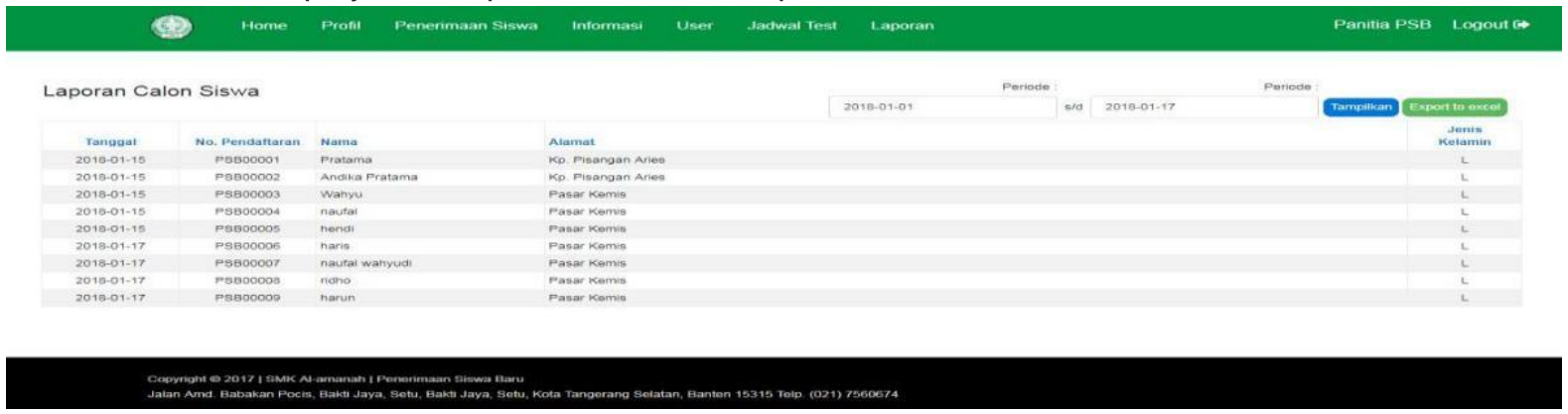

Figure 10. Display of Prospective Students Report

Figure 10. the picture above is the result of the implementation of the previous design, to provide information on new student data taken from the previous registration form.

- Display of prospective students who register with the Admin 


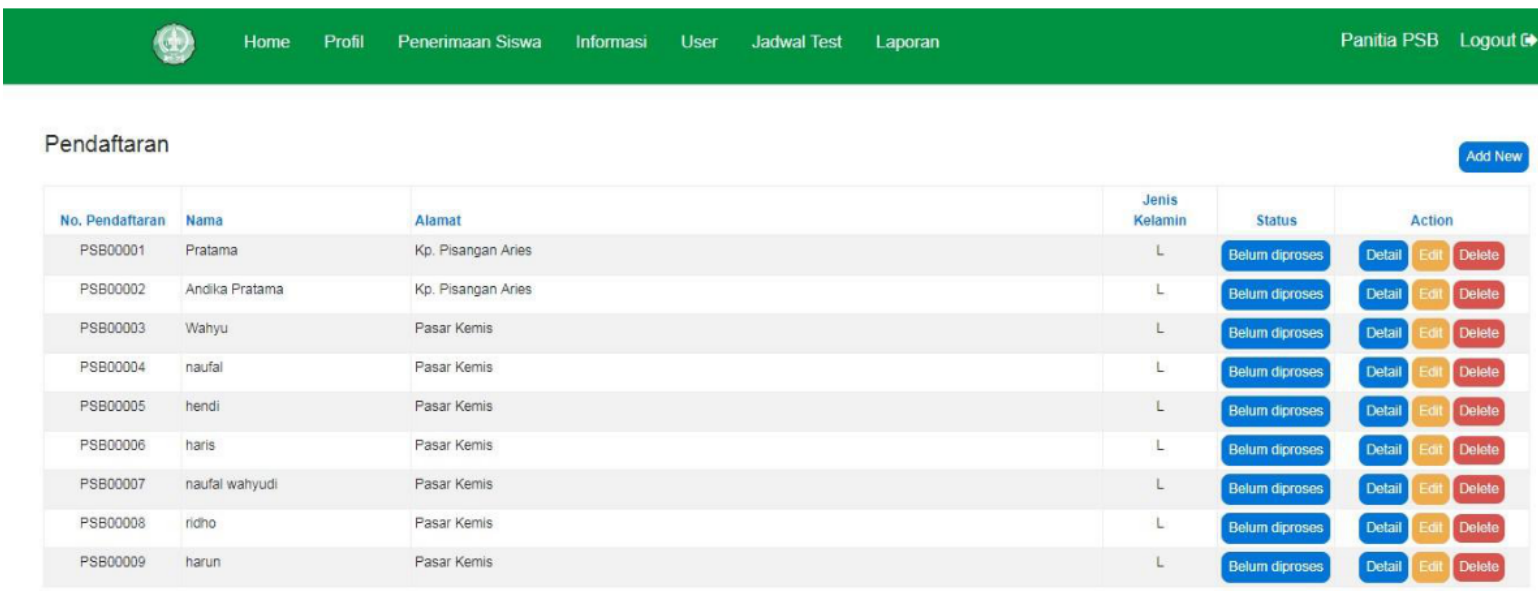

Figure 11. Display of Prospective Students Who Register With the Admin

Figure 11. the picture above is the result of the implementation of the previous design, to provide information to the admin to see and check the status of prospective new students along with the details and data of him.

\section{Conclusion}

Based on the results of the research and observations that have been made, it can be concluded that the research objectives include:

1. Practical Benefits It is expected that it can be used by employees or new student admissions committees. In the process of admitting new students, selecting new students, and making new student admission reports. With this program to get more effective and efficient results

2. Theoretical Benefits to improve the quality and service of schools, especially in the process of admitting new students and expected to increase the quantity of students.

3. Benefits of Policy As material for consideration for SMK Al Amanah Pasar Kemis to be used as a service to receive new students

\section{References}

[1] Sunarya, P. A., bin Ladjamudin, A. B., \& Dewanto, I. J. (2017). HUBUNGAN ANTARA MANAJEMEN WAKTU DENGAN PRESTASI BELAJAR MAHASISWA PROGRAM STUDI DIII KOMPUTERISASI AKUNTANSI AMIK RAHARJA INFORMATIKA. CICES, 3(2), 115121.

[2] Muslihudin, M., \& Larasati, A. (2017). Perancangan sistem aplikasi penerimaan mahasiswa baru di stmik pringsewu menggunakan php dan mysql. Jurnal TAM (Technology Acceptance Model), 3, 32-39.

[3] Yusup M, Rahardja U, Oktaviani S. GO+ Dalam Menunjang Int+ Untuk Pengelolaan Data Cmb Pada Perguruan Tinggi. CCIT Journal. 2014;8(1):65-82.

[4] Yusup, M., Rahardja, U., \& Oktaviani, S. (2014). GO+ Dalam Menunjang Int+ Untuk Pengelolaan Data Cmb Pada Perguruan Tinggi. CCIT Journal, 8(1), 65-82.

[5] Tiara K, Nurhaeni T. Penerapan Viewboard GO+ Berbasis Yii Sebagai Media Monitoring Pembayaran Mahasiswa. Technomedia Journal. 2016 Dec 2;1(1):65-77.

[6] R Al, N. A. Y. R. S., \& Tegal, I. (2011). Pembangunan Sistem Informasi Penerimaan Siswa Baru Di Sekolah Menengah Kejuruan Al-Irsyad Tegal. Speed-Sentra Penelitian Engineering dan Edukasi, 3(3). 
[7] Putri, L. D., \& Ahmadi, A. (2014). Perancangan Sistem Informasi Penerimaan Siswa Baru Pada Sekolah Menengah Kejuruan Negeri 3 Pacitan. IJNS-Indonesian Journal on Networking and Security, 3(4).

[8] Wijaya, S. W. S., Mulyanto, A., \& Mustakim, M. (2010, November). Sistem Informasi Penerimaan Mahasiswa Baru Berbasis WEB dan WAP. In Seminar Nasional VI, Yogyakarta(Vol. 18).

[9] Muslihudin, M., \& Larasati, A. (2017). Perancangan sistem aplikasi penerimaan mahasiswa baru di stmik pringsewu menggunakan php dan mysql. Jurnal TAM (Technology Acceptance Model), 3, 32-39.

[10] FARKHATIN, N. (2015). Perancangan Sistem Informasi Penerimaan Siswa Baru. Faktor Exacta, 5(2), 124-132. 